\title{
ENERGY AND RAW MATERIALS
}

The following series of sketches are devoted to the distribution and geological setting of the energy and mineral resources of Europe, as well as the history of their exploration and utilization.

\section{European Mineral Wealth}

\author{
by
}

\section{A. Ziserman, J. Bertraneu and M. Jaujou}

\section{Introduction}

Flint mines dug by Neolithic man on the frontiers of Belgium, Holland and Germany (Rijckholt) and in southern England are among some of the oldest known mines in Europe. When the art of metallurgy spread through the Middle East, mining activity expanded in Europe under the Phoenicians, Greeks and Etruscans. The Romans, and later the Saxons and the British as well, became leaders in the mining arts.

Most of the ancient mines are working today: Almaden (Spain), opened by the Phoenicians, is still the largest mercury mine in the world (Fig. 1); Laurion (Greece), whose silver helped to finance the birth of Athens, is still a centre of mining activity; Rammelsberg in Germany celebrated 1000 years of activity in 1968 .

Highly industrialized western Europe is also an enormous consumer of ores and metals, and now depends largely on imports to satisfy its needs. The following table illustrates this.

RESERVES, PRODUCTION AND CONSUMPTION OF SOME
KEY MINERALS IN WESTERN EUROPE $(1977)^{1}$

In the last twenty years, there has been a definite renewal of mineral exploration in Europe, and several notable successes have been recorded.

\section{Main mineral-bearing areas}

In Europe, geological diversity from the Precambrian to the Alpine orogenies has assured a relative abundance of ores. The distribution of principal mineral deposits referred to in this summary is shown in Figure 1.

The Precambrian shield is exposed (as noted elsewhere in this issue) over large areas in Scandinavia; it is also found at very shallow depths in the Ukraine. It holds the very important iron ores of Kiruna (Sweden), Kursk and Krivoi Rog (U.S.S.R.) which, are of volcano-sedimentary origin. Polymetallic sulphide masses are found in Finland along the suture between two orogenies of different ages. Ultrabasic rocks there contain $\mathrm{Cr}, \mathrm{Ni}, \mathrm{Cu}, \mathrm{Co}, \mathrm{Pt}$ mineralizations. Anorogenic intrusions of Proterozoic to Permian age cut through the Baltic Shield. In the Kola Peninsula they are more than 40 $\mathrm{km}$ in diameter and are associated with important apatite and rare metal ore mineralizations.

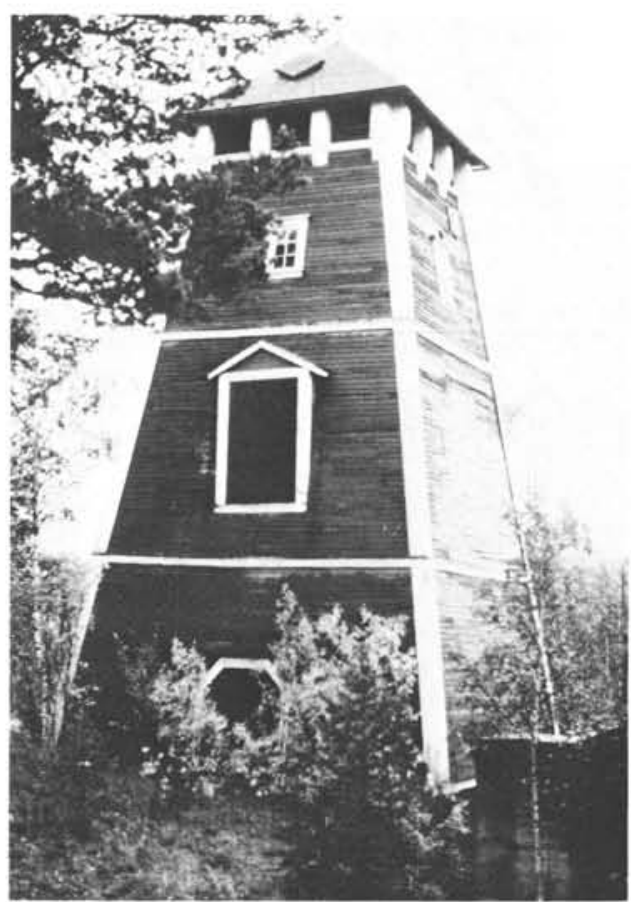

Old head frame at site of well-known former Orijarvi $\mathrm{Pb}-\mathrm{Zn}$ mine, Finland. (Photo courtesy D.F. Sangster)

The Caledonian chain, draped around Norway and the northern British Isles and fringing the Baltic Shield, is characterized by its numerous polymetallic sulphide masses, many of which are of Ordovician age, though few are large enough to be of great importance.

The deposits in the western Variscan (Hercynian) chain are numerous. Some are associated with Upper Carboniferous intrusions, such as those of Cornwall and Erzgebirge (which have supplied most of the European tin), and the Iberian basement (which is dominated by the tungsten province of northern Portugal). Polymetallic sulphide masses are found in Portugal and Spain (Rio Tinto), across Germany (Meggen) to Moravia; the most important masses are of Devonian or Lower Carboniferous age. $\mathrm{Pb}, \mathrm{Zn}$ and $\mathrm{Cu}$ veins, and uraniumbearing episyenites or stockworks were emplaced in Permian time. Still later, in the Triassic or even the Lias, veins and stratified deposits with $\mathrm{F}, \mathrm{Ba}, \mathrm{Pb}$ and $\mathrm{Zn}$ form a transition into the cover rocks.

The Urals have an abundance of copper, localized in polymetallic sulphide masses of Devonian age, as well as basic and ultrabasic rocks with $\mathrm{Fe}$ in the north and $\mathrm{Cr}$ in the south.

The Alpine chain bordering the Mediterranean is noted for its porphyry copper deposits in the Balkans and polymetallic deposits (with $\mathrm{Cu}, \mathrm{Pb}, \mathrm{Zn}, \mathrm{Sb}, \mathrm{Hg}, \mathrm{Au}$ and $\mathrm{Ag}$ ) associated with the Neogene propylitized vulcanics, which extend from Andalusia through Slovakia and the Carpathians to Iran and beyond. Basic and ultrabasic intrusions in suture zones host important $\mathrm{Cr}, \mathrm{Cu}$ and $\mathrm{As}$ deposits, as in other orogenic 


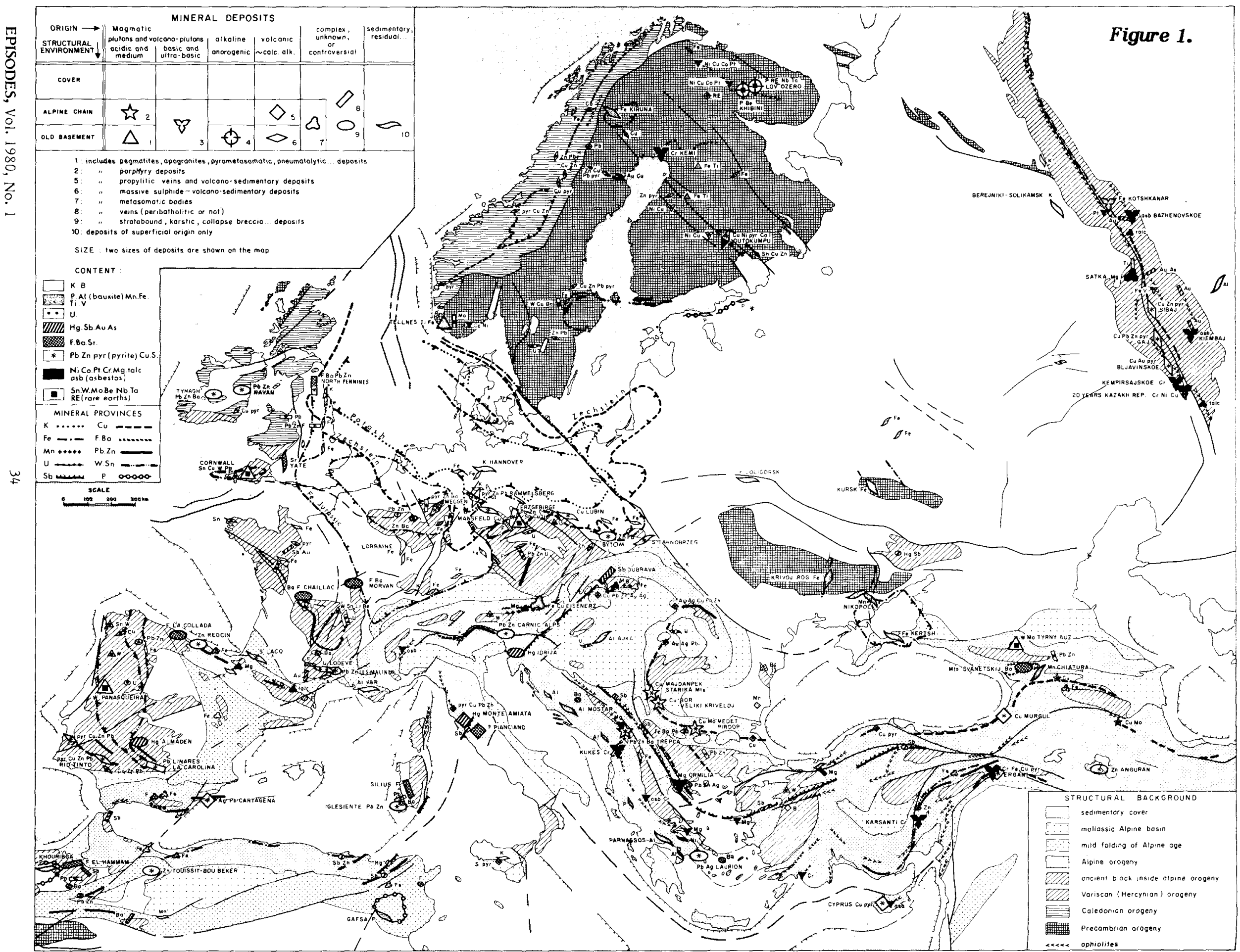




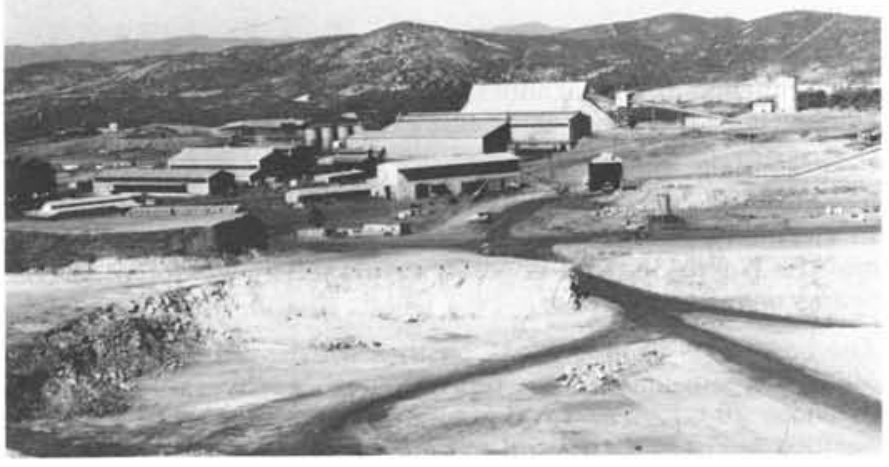

View to north of Cerro Colorado pit and mineral processing plant, Rio Tinto, Spain. (Photo courtesy R.V. Kirkham)

regions. Metasomatic masses of iron (hematitic or sideritic), magnesite and talc are common. Palaeozoic or Precambrian carbonate rocks caught up in the Alpine chains are found in many cases (such as at Laurion, Greece and Anguran, Iran) to contain large deposits of $\mathrm{Pb}, \mathrm{Zn}, \mathrm{Ba}$.

The strata of the sedimentary cover, contrary to generally held views, contain large mineral deposits. For example, the Permian was an important period for the formation of the potash near Hanover (F.R.G.) and Soligorsk (U.S.S.R.) and for copper at Mansfeld (F.R.G.). The Jurassic is well known for its oolitic iron ores of northern Europe, the largest deposit of which is in Lorraine, France.

In Cretaceous times, bauxites were formed from Spain through to Turkey; the Black Sea manganese (Nikopol) is of Eocene age and is similar to deposits at Varna (U.S.S.R.) which are of sedimentary volcanic origin; the Maghreb phosphates of north Africa are of the same period. Sulphur, potash and uranium were deposited in Alpine molassic basins at different times during the Tertiary era.

\section{Conclusion}

A detailed analysis of the distribution of deposits would show that around the margins of the orogenic belts that constitute the framework of this summary, mineral concentrations of Europe are in many cases arranged in a fairly geometrical pattern. They occur in complexes with metallic zoning which encircle the great prominent structures. They seem to point to geochemical characteristics of particular regions of the earth's crust, for which orogenies have acted merely as successive mobilizers of a fundamental inheritance. Here, the concept of the metalliferous province (L. de Launay, 1913) finds its true expression.

Europe can be divided in two by a great NW-SE line of fracture, with the Urals and the Scandinavian shield at the top on the right, and the Alpine chain and Variscan Europe below and to the left. This is the Tornquist line, as referred to by A. Simonen in Figure 2 of this issue of EPISODES. Another line, running from Tunisia to Slovakia, divides the lower part. Its course is marked by mercury and antimony deposits of very recent date. To the west lies Variscan Europe with its potash-bearing and copper-bearing Permian and iron-bearing Jurassic cover. To the east, the Alpine chain is rich in ores associated with ultrabasic rocks $(\mathrm{Cr}, \mathrm{Cu}$, pyrite, asbestos, $\mathrm{Mg}$ ), or with volcanoes or plutons $(\mathrm{Cu}, \mathrm{Pb}$, $\mathrm{Zn}, \mathrm{Ag}, \mathrm{Au}, \mathrm{Sb})$ of Andean cordillera type. Recent work by Routhier (1977) and others shows that distributions worked out for each metal on a detailed scale greatly assist in the accurate selection of future targets for mineral exploration.

\section{References}

de Launay, L., 1913, Traité de métallogénie: Librairie polytechnique $\mathrm{C}$. Béranger, Paris et Liège, $3 \mathrm{v}$.

Routhier, P., 1977, Vers un schema unitaire de la metallogenie régionale: Chron. Rech. Minière, 45 , No. 436, p. 11 22.

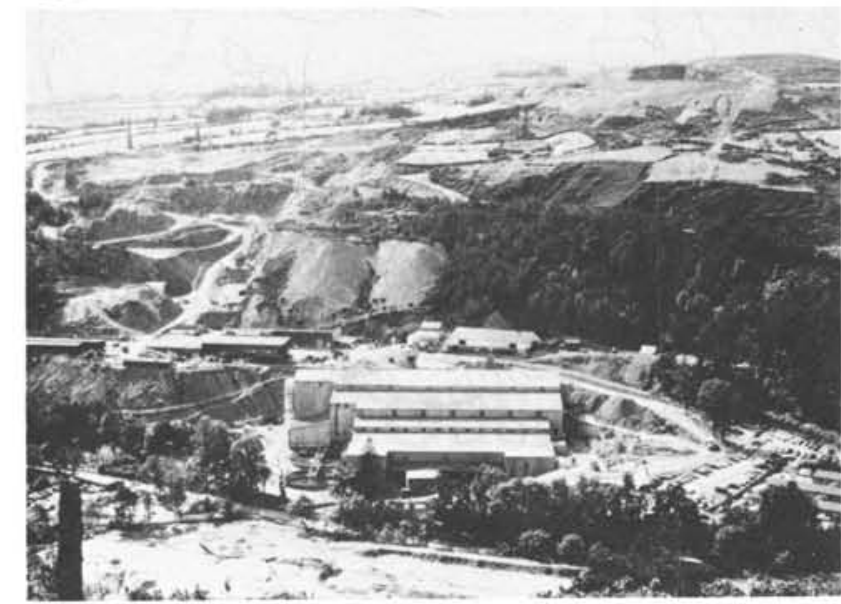

Mine site of volcanogenic massive sulphide ore body (chiefly copper), Avoca Mine, Ireland. (Photo courtesy D.F. Sangster)

\section{ABOUT THE AUTHORS:}

Jacques Bertraneu, an engineering graduate of the Ecole Nationale Supérieure de Géologie de Nancy in France, started his professional career as a mining geologist with the Algerian Bureau de Recherches Minières. For the past 20 years, he has been in charge of mining research at the BRGM, France.

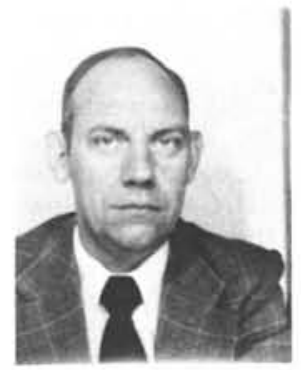

Head of the 'Departement politique des matières premières' (mineral policy) at the BRGM, France, Michel Jaujou graduated from the University of Paris (Sorbonne) as a mining geologist, following which he spent ten years mapping and prospecting in the Southern Sahara.

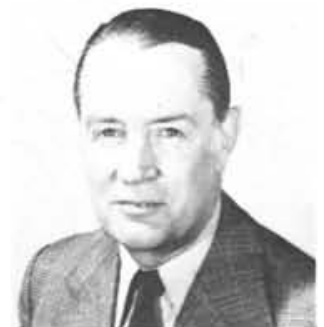

Since 1962, Alain Ziserman has served as a geological and mining consultant in the ore deposits branch of the BRGM, France. Dr. Ziserman is on staff at the University of Paris (Sorbonne) and lectures also at the Alès School of Mines. A co-author of the Metallogenic Map of Europe, his research interests have included $\mathrm{Pb}, \mathrm{Zn}, \mathrm{Ba}, \mathrm{F}, \mathrm{Cu}, \mathrm{Hg}, \mathrm{Sb}, \mathrm{Au}, \mathrm{As}, \mathrm{W}$, and $\mathrm{Sn}$ deposits in France, Spain, Turkey, Iran, Brazil, Peru, Bolivia and Rwanda.

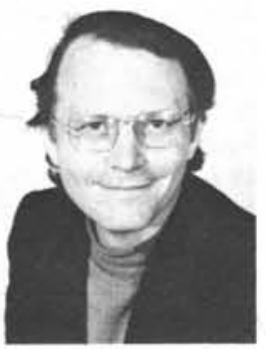

